\title{
CONCEPTS FOR GEOTECHNICAL INVESTIGATION IN KARST
}

Joseph A. Fischer

Geoscience Services, 1741 Route 31, Clinton, NJ 08809

\section{Joseph J. Fischer}

Geoscience Services, 1741 Route 31, Clinton, NJ 08809

\section{Abstract}

There seems to be a lack of recognition in the literature that addresses the variety of karst in the United States of America and some of its offshore territories. For example, there are the well-known solutioned carbonates of Florida and the Caribbean, but there are also the somewhat older, harder carbonates of St. Croix, U.S.V.I. Even Florida's recently deposited karst varies from region to region. There are also the ancient, flat-lying carbonates of the interior craton that often have semihorizontal cavities resulting from variations in ground water levels affecting bedding and the contorted rocks of the Appalachians with its apparently chaotic variations in solutioning found across-strike and in relation to folds, faults, and fracturing. In addition, there are various salt and gypsum deposits in the south and southwest that pose their own problems to man's works.

As the geology differs, so does, to some extent, the investigation requirements, investigation techniques and engineering solutions. There is no single set of investigative tools that fit all karst sites. Geophysical investigations are apparently far less suitable for the broken and twisted Appalachian karst than in the flatlying mid-continent carbonates or the less contorted "karst" of Florida.

Specific procedures developed for geotechnical investigation in true karst have been documented for many years now. However, it appears that many practitioners are not aware of them or choose not to use them because of the possibility of increased costs; or too often, a lack of geotechnical understanding of the work of others in karstic areas outside their sphere of experience.

This paper will attempt to provide a rational geotechnical approach to carbonate rock investigations in the United States while recognizing the inherent variabilities of the targets and the economics of pre-construction investigations; with the understanding that one size does not fit all.

\section{Karst Variability}

Carbonate bedrock is found throughout the world. Spectacular examples of true, pinnacled karst are found in China and the namesake plateau in Slovenia and Italy. However, all carbonates are not the same, although this distinction is often overlooked by investigators. They range in strength and character from the soft offshore corals of the Caribbean Islands and Florida to marbles. More confusion is added by having the older, hard, but flat-lying carbonates of the central US, the hard, stressed, folded and fractured limestone, dolomites and marbles of the Appalachian Mountain chain and the soluble gypsum (evaporite) of the southwestern US (which can form sinkholes that dwarf the well-publicized ones of Florida).

As can be deduced from the extensive portion of the US underlain by karst (Figure 1), development growth has likely forced administrators, politicians, the public, as well as engineers and geologists to recognize the concerns of building atop karst. The result has sometimes been environmentally aware regulation and better technical understanding to address the problems posed by this variable and generally disguised environment. We can no longer conscientiously drill three or four test borings to characterize a 500-acre site for construction or use one boring per mile to address the engineering concerns along a roadway or transmission line in karst and assume that we have all the information necessary for evaluation and design of structures.

Geotechnical analyses and recommendations are not the same for all conventional (non-karst) sites, but they are even more varied and complicated for karst sites. In formulating a site study/evaluation, one must appreciate; A) The potential variations in physical properties across and below a site, B) the applicability and appropriateness of the available suite of site investigative tools, and C) the availability or lack of potential planning and/or engineering solutions to cover the uncertainties that will likely exist at the karst site in question. 


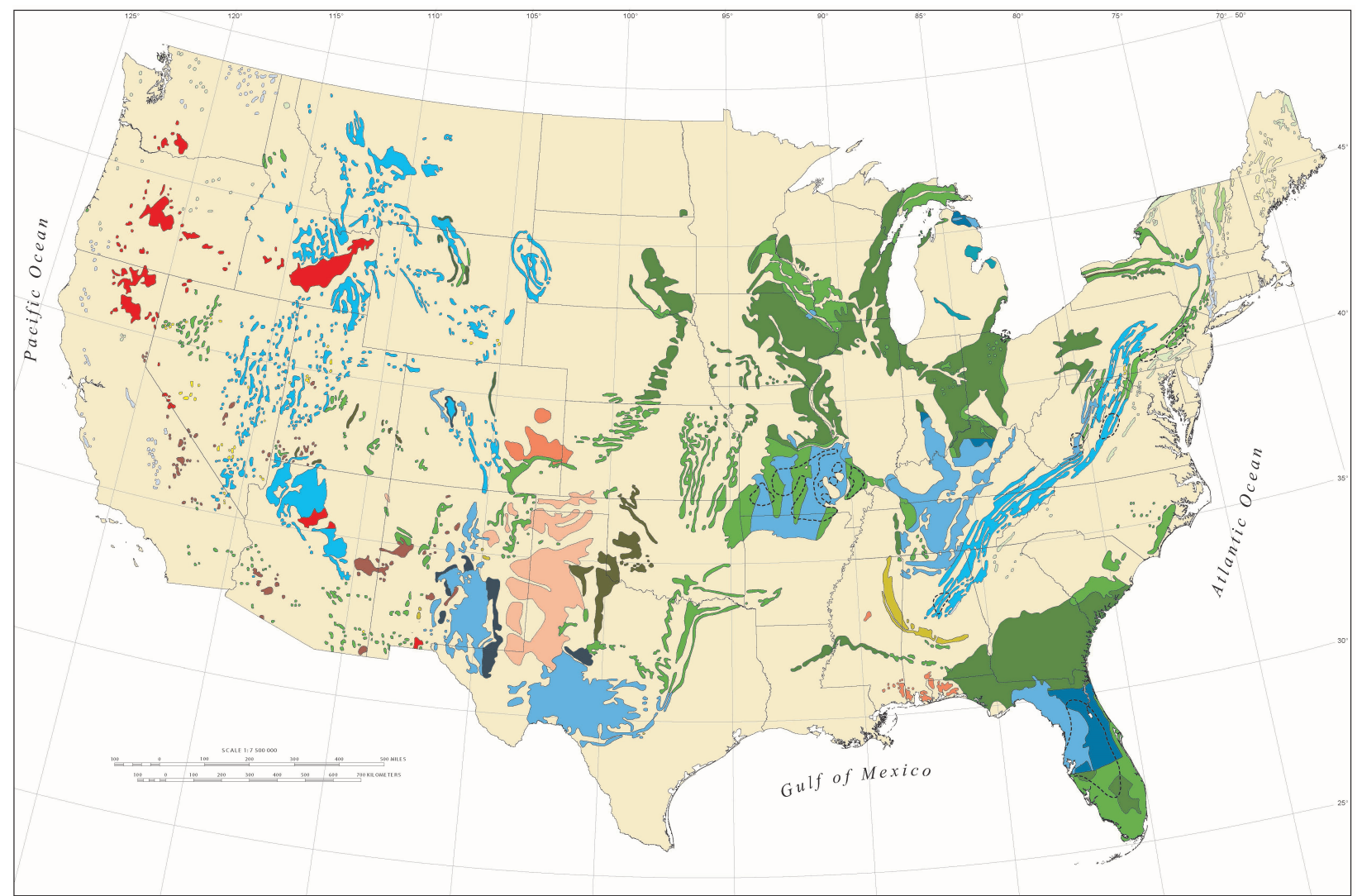

Figure 1. National Karst Map showing portions of US underlain by karst (from Tobin and Weary, 2004).

The intention of this paper is to point out the difficulties of performing geotechnical investigation in karst as a result of the differences in bedrock ages, degree of deformation and perhaps most important, the degree of tectonism experienced by the bedrock in different regions. Not all karst is the same; not all the exploratory tools used or the manners in which geotechnical investigations are performed should be the same for all types of karst. It should be noted that our experience has been in "limestone" $\left(\mathrm{CaCO}_{3}\right)$, dolomite $\left(\mathrm{CaMg}\left(\mathrm{CO}_{3}\right)_{2}\right)$ and/or marble, we will allow others to comment on gypsum $\left(\mathrm{CaSO}_{4} \cdot 2 \mathrm{H}_{2} \mathrm{O}\right)$ and other evaporites.

Another aspect that must be considered is the existence of local or State ordinances regulating either the construction or impact allowed at karst sites. These regulations, where they exist, can have different intentions. For example, many municipal "limestone" ordinances in Pennsylvania are primarily directed toward inhibiting development; Virginia's toward protecting ground water; Michigan's toward control of feed lot expansion; and New Jersey's generally toward limiting construction on karst or providing a means of development of the site conscientiously, not necessarily economically.

\section{Geology}

For simplicity, this paper will attempt to crudely divide this presentation into three groups of karst.

- Old, mid-continent, generally flat-lying carbonates,

- Old, folded and faulted Appalachian carbonates, and

- Recent, coralline limestone.

For those interested in a more precise division, we suggest the United States Geological Survey (USGS) compilation Characterizing Regional Karst Types under the Framework of the New National Karst Map (Weary et al., 2008). Generically, the differences are age and degree of tectonism. The USGS further differentiates US karst types by thickness of the overburden and precipitation. The overburden thickness of concern to the geotechnical community are generally less than 
100 feet; although mining, some dams and similar large construction can be exceptions. The recent New National Karst Map (Figure 1) also includes the areas underlain by evaporite karst, which are not covered in this paper.

All of the aforementioned karst types of concern were originally deposited in warm, relatively shallow seas. Deposition or coral growths continue today in the warm waters of the Atlantic Ocean and Caribbean Sea. The older carbonates (Cambro-Ordovician-aged) have been subjected to a variety of stresses and, in the Appalachian Mountains, a series of orogenies resulting in faulting, folding and fracturing (and some metamorphism) along what was the Atlantic coast approximately $300+$ million years ago.

The mid-continent carbonates are generally the same age as the Appalachian rocks, but have not been subjected to the same orogenic forces, but did experience some of the stress fields caused by several openings and closing of the proto-Atlantic Ocean.

\section{Geologic Concerns}

The occurrence of sinkholes (dolines) swallowing buildings, automobiles, farm equipment and people has been well publicized. Less well recognized are the settlement of structures (including dams) and sinkhole occurrences in roadways, in backyards, below swimming pools, farms, manure storage facilities, railroad structures, fuels storage areas and bridge abutments. Less recognized hazards exist such as creating flooding and compromising stormwater detention/retention/ infiltration systems, thus allowing contaminants to reach ground water supplies.

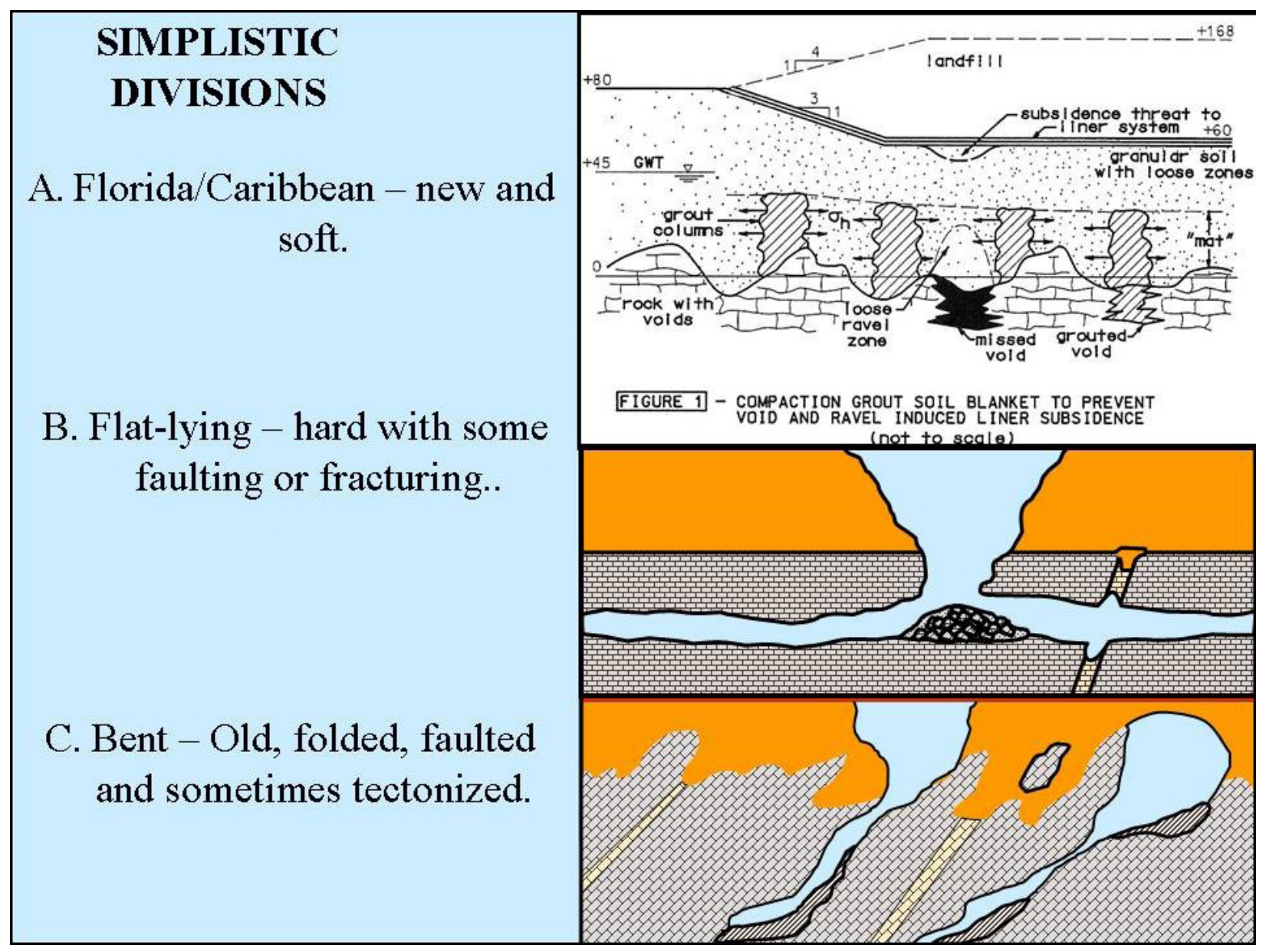

Figure 2. Representation of the simplistic divisions of United States karst (Section A from Schmertmann and Henry, 1992). 
The irregularity of the Appalachian, as well as some recent, softer Florida-type bedrock surfaces presents additional concerns in its effect upon the ground surface, further complicating geotechnical evaluations (Figure 2). Long and sometimes sinuous conduits are common in the central US's flat karst (e.g., Mammoth Cave). Both lateral and vertical variations in the overburden materials (thickness and properties) are more common in the Appalachians. After a visit to almost any commercial cave, one can visualize the effects that changing ground water conditions over time have had on the bedrock. These differences in rock type, age of deposition and the range of effect from tectonism have to be considered in geotechnical investigation and for potential remedial solutions in these various environments.

\section{Geotechnical Evaluation}

The first step in developing a program of investigation is to expand upon the knowledge of the geology in the area or site of concern. State and Federal agencies generally have a wealth of information concerning subsurface conditions. These data can include:

1. Bedrock types and their expected depth below grade.

2. Driller's logs and well yields from specific locations or geologic formations. These data can provide clues to the degree of fracturing and or solutioning found within various formations. However, we must be aware of driller's classifications such as "gray rock".

3. The existence and density of caves, sinkholes and disappearing streams.

4. The existence of known or suspected faulting, antiforms and synforms (i.e., where the bedrock has been stressed and subjected to deformation) where increased solutioning is likely to be experienced.

5. Bedrock strengths and quality of overburden.

6. Textural classifications that can provide a clue to material solubility.

Be aware that similar rocks and soil types do not necessarily have the same formation names from State to State.

\section{Geotechnical Engineering}

Sinkholes are an obvious concern in areas underlain by carbonate bedrock. Pictures of huge holes in the ground swallowing cars and houses make for big news. However, much of the older rocks can be quite hard when protected from weathering. For example Mammoth Cave in Kentucky and the Natural Bridge in Virginia.

Considering the expected lifetime of many construction projects, founding on these materials can still be an appropriate approach. The unconfined compressive strength of Cambro-Ordovician limestones and dolomites can be on the order of 10,000 to 15,000 pounds per square inch. As a result, the roof over a cavity can sometimes support large loads; though if it fails it will likely be well-documented.

However, the weak, recent corals of Florida and the Caribbean are not as friendly. Flying over the flat lands of Florida it is possible to see large, circular, water-filled sinkholes dotting many areas. Aerial photographs of such a Florida landscape can be most diagnostic, especially if linear patterns and/or frequency of occurrence can be determined. These images can also be troubling to an owner, developer or geotechnical investigator.

However, even the relatively weak, recent corals of Florida and the Caribbean can support significant loads where not compromised by solutioning. Although the Schmertmann and Henry representation of Figure 2 (Section A) may somewhat exaggerate concerns at a Florida site, the concerns remain.

There are a number of engineering solutions to founding structures, roads, utilities, detention/retention basins and tunneling in karst. The basic problem is evaluating the subsurface conditions satisfactorily and to define the solution in a reasonably economic manner. So, it becomes somewhat of a balancing act. There is a need to find suitable materials to carry the proposed loads during the economic life of the structure. The problem is more complicated than it would be at most non-karst sites. One of the problems of founding on Appalachian karst over a more conventional site is compounded by the variability, both laterally and vertically, of the seams and fractures, and the general subsurface conditions. The material properties of these contorted rocks can vary significantly over short distances. 


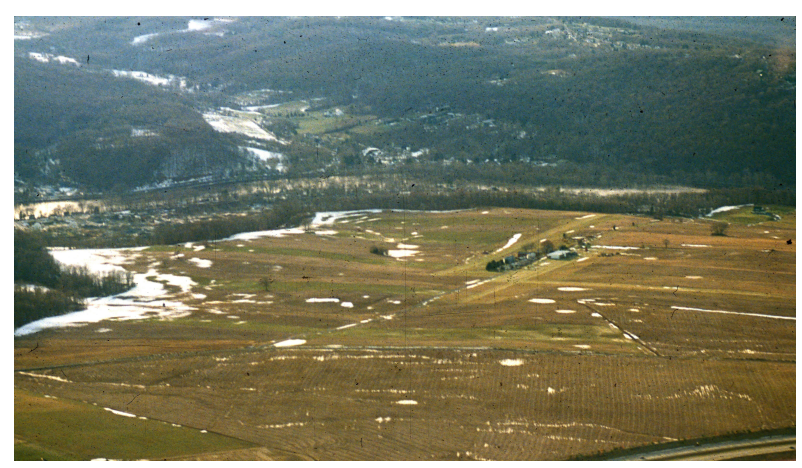

Figure 3. Aerial photograph of western New Jersey karst site.

Florida and mid-continent karst concerns can be caused by the lateral and vertical movement of ground water, with the effects being greater over shorter periods in the softer Florida and Caribbean karst.

Can the investigator sample enough locations on the site, either by direct or indirect means, to provide an appropriate support solution for such a variable subsurface? Imagine the difficulties of investigating a site such as the one shown on Figure 3 for the development of a satisfactory model of the subsurface. The many variables related to different karst areas of the US make it virtually impossible to answer all site related questions definitively before the start of construction. Hence, any construction-related planning should consider contingencies for increased costs for both inspection and the possibility of additional or supplemental remediation.

In addition, the construction process itself can create unstable or weakened conditions. Often, there is poor control of surface and ground water during construction of a facility. Excavation at a site can remove a protective layer of low permeability soils over solutioned rock, and pond water in these compromised areas. Ground water can travel along the top of the bedrock surface until it finds an entrance into a cavity, eroding soils from directly atop the bedrock and increasing the area of concern. Changing the hydraulic head and/or flow rate at a construction site, either by cut or fill, might alter otherwise stable conditions. The effects of changing the hydraulic conditions at karst sites are exemplified by the failure or remediation of many dams built atop karst. Also, the potential for ground water contamination is much higher in karstic environment by decreasing filtration in overburden soils and increasing the speed that contaminant can reach a receptor.

\section{Preliminary Site Evaluation}

In any "limestone" investigation, the "best bang for the buck" is usually the results of the initial stages of a site study. The first step is a review of any available data from federal and state sources including environmental reports and studies performed for nearby sites.

Aerial photos of the site are, whether from aircraft or satellites, highly valuable and often available from archives. A series of aerial photos taken over time can show changes in vegetation, landforms, farming practices, etc. For example, why is a tree standing alone in the middle of a cultivated field? Karst features can develop over time and then later masked by farming practices. Aerial photos taken in the early spring (before tree cover) and during wet years (e.g., Figure 3 ) can show changes in moisture that can be quite telling. Persistent linear and circular features are particularly suspicious if noted in photos taken over time or on LiDAR. Even drought-induced "crop lines" have been used as a tool in delineating potential sinkhole locations (Panno et al, 2013). These features should be further investigated by a site reconnaissance to help in identifying any noted features for use in a subsurface model.

In the past, sinkholes had many uses, garbage receptacles, debris pits and even as unrealized flood control aids. Areas that have been mined or quarried can indicate mineralized zones that can have an increased susceptibility to solutioning. In Appalachian karst the ground elevation variations can be more severe than observed from a windshield reconnaissance. Standing on a high point overlooking a site or flying over a large site at low altitude can be very informative, particularly within more flat-lying areas. We have observed sites as pockmarked with sinkholes as a World War I battlefield.

If effectively utilized, an experienced engineering geologist/geotechnical engineer can develop a great deal of insight from a well-rounded site evaluation performed early in the site selection or development process. This initial phase, even though quite economical, can be used to determine the intensity of subsequent site investigations and/or whether a site or route should be abandoned. 


\section{Site/Route Investigation}

If the site or selected route seems economically and technically viable, then it is likely that some additional geotechnical study will be required. Obviously, the nature of the project will change the character of the investigation. It is often advisable to phase future investigations.

The information most desired at any karst site is the distribution and dimension of soil voids and bedrock cavities, and whether those cavities or voids are filled with water or soil. Also necessary is some knowledge of the bedrock surface variations. The expected variations in the bedrock surface will differ largely from relatively flat mid-continent rocks to Florida's variable and generally soft carbonates and the even more erratic, hard Appalachian rocks.

Another consideration is what effect the planned construction would have on local ground water supplies, which can be influenced even from considerable distances in a water-filled cave system. Dye studies performed by knowledgeable and aware professionals seems to be the only way of assessing possible ground water concerns and travel paths that new construction atop karst can effect. Exploring caves (spelunking or diving) by the more adventurous investigators can be very useful, although dangerous.

A host of geophysical procedures have been espoused as an effective investigative tool. These techniques include seismic reflection, refraction and tomography, electrical conductivity and resistivity, self-potential, ground penetrating radar, gravity, and Spectral Analysis of Surface Wave (SASW) methods. Apparently, the best results in the use of geophysics at karst sites have been a combination of geophysical procedures coupled with test borings (Benson, et al, 1998).

The efficacy of investigating with a single geophysical tool, using air-track probes and test borings to calibrate the results in Appalachian karst, is unfortunately exemplified by the following statements by one geophysicist in his report of a resistivity survey: "Generally, resistivity data is very good with good repeatability and trends that correlate well from intersecting and adjacent survey lines." Followed later by: "The results of the survey show several different subsurface conditions. Detected by the survey are possible sinkholes and possible depth to bedrock

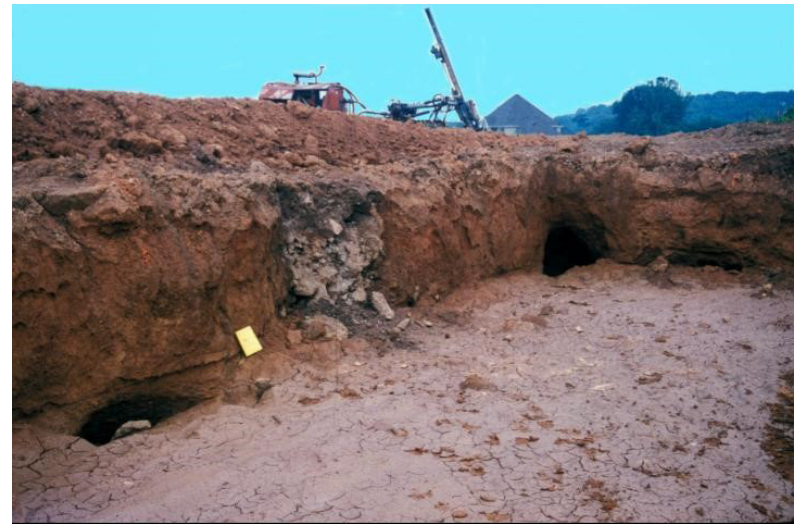

Figure 4. Evidence of past and ongoing sinkhole formation in house foundation excavation.

variations. Differences in results from the drilling program may be caused by geologic differences affecting the electrical properties of the subsurface materials, modeling parameters, and orientation of the electrode array." Apparently, even the geophysicist could not correlate the survey results into a coherent model in Appalachian karst. This geophysical investigation did not seem to be a useful tool for characterizing this site's subsurface conditions in preparation for any kind of development.

Thus, it appears that geophysical procedures alone will not yield the answers to many karst concerns and can, at best, be interpreted with the aid of test borings and probes drilled by experienced, cooperative personnel under the technical direction of experienced field personnel including geophysicists.

Test pits can be performed in a conventional manner and can be very informative if portions of the rock surface can be exposed. Potential signs of solutioning can be deduced from near surface-effects. Is the weathered bedrock relatively uniform and straightforward or is there evidence of leaching or groundwater movement? Are the remains of an old, filled sinkhole obvious in the pit walls or bottom (Figure 4)? Is relict bedding distinguishable in the pit wall?

Test borings should be drilled using rotary-wash techniques without the use of drilling mud whenever possible so that drilling water loss depths and quantities can be monitored. In clean, sandy soils this may not be possible, but drilling with augers and periodically introducing water (say between samples) or the use of a light mud where necessary 
should allow for drilling fluid losses to be monitored while keeping the boring open.

Drilling water lost at the top of the rock usually indicates a down-gradient channel or the gradual erosion of soil into open bedrock solutioned passages. Soft soil zones are often observed atop the bedrock surface or adjacent to pinnacles. Conventional soil sampling techniques are generally adequate. Although providing water to the drilling site can become a logistical problem, it can be mitigated by casing off zones of significant water loss.

Encountering a karstic bedrock surface can be quite eventful. Carbonates have many faces; will it be sound, weathered, broken, a bedrock pinnacle or an erratic boulder, or saprolite below sound rock? Coring most carbonate rock is best done using double- or tripletube, split core barrels. At least one spare core barrel should be on hand as the variable conditions that can be encountered are often hungry for drilling equipment utilized less than cautiously.

The information that can be observed from cores derived from a split core barrel is far more representative of the actual bedrock conditions and well worth the increased expense of its use. Fracture frequency and orientation is more easily observed and fracture and cavity filling is often captured in the barrel, along with highly weathered zones; all of which could be lost or minimized by hammering the core from a non-split barrel. Again, experienced drillers and competent inspectors are essential.

\section{Foundation Design Considerations}

Most foundation solutions are available for use once the scope of the subsurface concerns is recognized. The most commonly used sinkhole stabilization solutions are; A) excavate to sound rock and backfill to building grade, B) transfer construction loads to sound rock or bypassing the area of concern, C) densifying overburden materials and D) grouting of cavities with non-shrinking materials. Whatever concept is chosen, the execution should be flexible and hopefully cost-effective.

\section{A) Excavate to Sound Rock and Backfill}

The simplest is excavation to sound materials and returning the area to grade with compacted fill (sometimes after dental grouting of bedrock openings) or even lean concrete if the excavation is shallow enough. The unfortunate part of such a program is the need for enough quality subsurface information to be able to generate accurate excavation and backfilling costs. A pinnacled bedrock surface makes this very difficult.

For example, the Maryland State Highway Administration (MDSHA) responded to a large sinkhole immediately adjacent to a major interstate highway. The sinkhole was 110 feet long by 30 to 35 feet wide and 35 feet deep at the throat. In an effort to keep the highway embankment stable, the sinkhole was quickly and partially backfilled with some 2,700 cubic yards (cy) of quarry waste. Unfortunately, while drilling to place grout, the rock surface was revealed to be quite variable, necessitating an additional 2,045 cy of grout to fill the subsurface cavity. The maximum bedrock depth encountered was 100 feet (Martin, 2004). Even with the local geologic information available from highway construction and local quarry operators, they could not anticipate the extent of the weakened or missing subsurface materials.

\section{B) Transfer Construction Loads to Sound Rock}

Transferring loads from weakened subsurface areas to those capable of supporting loads is another founding alternative in karst. Bridging openings in the bedrock surface or soft soils zones with a reinforced concrete pad have been used.

A common foundation solution can be the use of driven piles or caissons, particularly with the present day ability to drill through the pile or caisson shaft in order to evaluate the quality of the founding materials below the pile tip and to possibly introduce grout if conditions warrant.

Pin piles have often been used satisfactorily because the pre-drilling used for their installation allows an increase in knowledge of the subsurface conditions at the pile location. However, grouting the pin piles to bond them to the sides of the hole can require large amounts of grout and there can remain unsupported lengths through cavities and soft soil zones.

Mathematical models have been or can be developed to assess the load-carrying ability of cave or sinkhole roofs in order to provide a requisite number and type of deep foundations to be used. However, it is probably more economical to perform a one-time investigation/foundation solution such as drilling and grouting, or installing a pile foundation to resistance depths, then drilling through the pile 
shaft. The quality of the subsurface data needed to develop such a model for "arch support" and to install an extensive deep foundation would likely be more economical if the data were obtained simultaneously with foundation installation than in two separate phases with modeling time in between. There is no doubt that liaison between the designers and the on-site foundation installers are necessary in such cases.

\section{C) Densifying Overburden Materials}

The densification of the overburden materials is frequently performed in two ways; deep dynamic compaction (DDC) and compaction (i.e., low-mobility) grouting. DDC is simply the dropping a very large weight from a fixed height to impart a design energy to densify near-surface soils, collapse soil voids and clog bedrock surface openings with overburden soils. If the rock is shallow, cave roofs may also be collapsed.

The writers' have found that dynamic compaction ("dynamic destruction" in karst?) operations, coupled with test borings and or probes, have been successfully used in both defining the need for site remediation on Florida projects (FHWA, 1995) as well as being the preferred remediation. Dynamic compaction can be performed as a lower cost alternative to increased investigation while possibly solving many of the problems that would be encountered during construction.

Low-mobility grouting is often used to densify weak overburden soils in preparation for construction loads and has the benefit of also filling, at least partially, encountered voids and cavities. The drawback to such grouting is if voids and cavities get extensive, grout costs can escalate substantially. It is also a difficult method to use in sites underlain by moist clayey soils because of the slow rate of pore pressure decay.

\section{D) Grouting Cavities}

High-mobility grouting, with site mixed grout generally provide the most flexible and cost-effective means of remediating karstic subsurface conditions. The use of commercial "foaming" agents can reduce material costs yet yield strengths of 4,000 pounds per square foot or more, depending upon the constituents of the mix. That is usually more than enough strength to reinforce bedrock cavities and solutioned zones for most construction. However, such a grouting program does require a grout crew and supervising karst grouting professional that recognizes the nature of the "beast below" and are ready to respond.

\section{Conclusions}

There are many hundreds of square miles of the United States underlain by karstic soils and bedrock. Unfortunately, all karst is not the same, though this has not been as well recognized as it should. The media has enjoyed reporting on sensational sinkhole occurrences that have swallowed houses, cars and people, but even if an "expert" has been contacted, the geotechnical concerns that may have existed are treated in passing.

Geotechnical practitioners must be more communicative when dealing with property/facility owners, planners and engineers. Clients and designers should be made aware of the possible dangers lurking below as well the impact the karstic subsurface conditions could possibly have on their plans.

It is difficult to understand why more municipalities do not have appropriate "limestone" ordinances as some have been tested in court and proven legal. The same can be said about the geotechnical and structural design professions; few appear to understand the difficulties that can result from the existence of carbonate bedrock below a site. Obviously, experienced consulting is necessary to ensure sound construction in karst and in the development of "limestone" ordinances. These ordinances should be directed toward the varying conditions of an individual karst site, as well as the differences in karst from region to region as discussed herein.

As much data is available to the geotechnical engineer prior to planning a subsurface investigation, this should be utilized to its fullest in considering the target. Determining an appropriate investigation program for a karst site is dependant upon this knowledge, which can only be utilized to its fullest with experience.

\section{References}

Benson RC, Kaufmann RD, Yuhr L, Martin D. 1998. Assessment, prediction and remediation of karst conditions on I-70, Frederick, MD. In Proceedings of the 49th Highway Geology Symposium, 1998 Sept. 10-14; Prescott, Arizona. p. 313-325.

Federal Highway Administration. 1995. Dynamic Compaction, Geotechnical Engineering Circular No. 1. FHWA-SA-95-037.

Martin DA. 2004. Case History of the South Street Sinkhole, Frederick, Maryland. In Proceedings of the 55th Highway Geology Symposium, 2004 Sept. 7-10; Kansas City, Missouri. p. 81-93.

Panno SV, Luman DE, Kelly WR, Alschuler MB. 2013. The use of drought-induced "crop lines" as a tool 
for characterization of karst terrain. In: Land L,

Doctor, DH, Stephenson, JB, editors, Proceedings of the 13th Multidisciplinary Conference on Sinkholes \& the Engineering and Environmental Impacts of Karst; 2013 May 6-10; Carlsbad, New Mexico. Carlsbad (NM): National Cave and Karst Research Institute. p. 53-59.

Schmertmann JH, Henry JF. 1992. A design theory for compaction grouting. Grouting, Soils Improvement and Geosynthetics, ASCE Geotechnical Publication 30 (1): 215-228.

Tobin BD, Weary DJ. 2004. Digital Engineering Aspects of Karst Map: A GIS Version of Davies WE, Simpson JH, Ohlmacher GC, Kirk WS, and Newton EG, 1984, Engineering Aspects of Karst: U.S. Geological Survey, National Atlas of the United States of America, Scale 1:7,500,000.

Weary DJ, Doctor DH, Epstein JB, Orndorff RC. 2008. Characterizing regional karst types under the framework of the new national karst map. US Geological Survey Scientific Investigations Report 2008-5023. 
